\title{
OCCURENCE OF THE PATHOGEN PSOROSPERMIUM HAECKELI (HILGENDORF) IN ASTACID POPULATIONS IN CROATIA
}

\author{
A. LUCIC, I. MAGUIRE, R. ERBEN.
}

Department of Zoology, Faculty of Science, University of Zagreb, Rooseveltov trg 6, 10000 Zagreb, Croatia.

E-Mail: andreja@zg.biol.pmg.hr

Reçu le 6 janvier 2004

Accepté le 26 avril 2004

Received January 6, 2004

Accepted April 26, 2004

\begin{abstract}
Psorospermium haeckeli is a thick-walled unicellular organism widely reported in European astacid crayfish. It is typically referred to as a "parasite" although its pathogenic impact remains unclear. Until now there were no data about its presence in Croatian astacid crayfish. We examined 144 specimens of the three astacid species from 12 different locations and found sporocysts of Psorospermium in 13 preparations of epidermal connective tissue of Astacus astacus and Astacus leptodactylus. Preparations were made by scraping the epidermal-connective tissue from under the carapace, treating it with $10 \% \mathrm{KOH}$ and viewing it under a microscope at $125 \times, 250 x$ and $400 x$ magnification. A relative scale was used to describe the degree of infection of the crayfish by Psorospermium. We found two types of mature sporocysts and also some developing stages of Psorospermium. In the A. leptodactylus we found many sporocysts that were fully melanised. Further investigations are needed to understand the distribution of infected crayfish in Croatia and patterns of their infection with Psorospermium.
\end{abstract}

Key words: Psorospermium haeckeli, Astacus astacus, Astacus leptodactylus, Austropotamobius torrentium, Croatia

\section{APPARITION DU PATHOGÈNE PSOROSPERMIUM HAECKELI (HILGENDORF) DANS LES POPULATIONS D'ÉCREVISSES EN CROATIE}

\section{RÉSUMÉ}

Psorospermium haeckeli est un organisme unicellulaire à parois épaisse très répandu chez les écrevisses européennes. $P$. haeckeli est considéré comme un « parasite » même si sa pathogénicité reste encore non clairement définie. Jusqu'à présent il n'y avait aucune donnée concernant sa présence chez les écrevisses en Croatie. Nous avons examiné 144 spécimens de trois espèces d'écrevisses provenant de 12 stations et trouvé des sporocystes de $P$. Haeckeli dans 13 préparations de tissu conjonctif épidermique prélevé sous la carapace, préparé avec du $\mathrm{KOH} 10 \%$, et observé sous microscope aux grossissements $125 \times, 250 \times$ et $400 \times$. Une échelle relative a été utilisée pour décrire le degré d'infection des écrevisses par $P$. haeckeli. Nous avons trouvé deux types de sporocystes de $P$. haeckeli matures et quelques-uns en développement. Chez $A$. leptodactylus nous avons trouvé plusieurs sporocystes complètement mélanisés. De plus amples recherches sont nécessaires pour comprendre la distribution des écrevisses infectées en Croatie et le mode d'infection de Psorospermium.

Mots-clés: Psorospermium haeckeli, Astacus astacus, Astacus leptodactylus, Austropotamobius torrentium, Croatie. 


\section{INTRODUCTION}

Psorospermium haeckeli (Hilgendorf) is a thick-walled unicellular organism widely reported in European astacid crayfish (VOGT, 1999). Its taxonomic status has recently being elucidated; it is closely related to the similar organisms of aquatic pathobiology. They constitute the most basic branch of the Animalia provisionally named the DRIP clade according to the first letters of its member genera (Dermocystidium, Ichthyophonus, Psorospermium and rosette agent) (EVANS and EDGERTON, 2002). There are some speculations that DRIPs belong to the class Mesomycetozoea with $P$. haeckeli belonging to its lowest order of Ichthyophonida (MENDOZA, TAYLOR and AJELLO, 2002). At present, two morphotypes of Psorospermium sporocysts can be distinguished in European astacid on the basis of size, morphology and histology: an ovoid morphotype which includes numerous globules of heterogeneous size and an elongated morphotype which contains smaller and homogeneous globules (RUG and VOGT, 1995). Psorospermium is particularly abundant in the collagenous wall of the dorsal thoracic blood vessels and in the surrounding subepidermal connective tissue (VOGT and RUG, 1995). Compared to the other DRIP's Psorospermium seems to have very low pathogenicity (HENTTONEN, 1996) although it can interfere with the immune system of crayfish (THÖRNQVIST and SÖDERHAÄLL, 1993). Most publications dealing with Psorospermium describe these organisms as being relatively large (often over $100 \mu \mathrm{m}$ long), oval or elongated, filled with globules of different sizes within an outer thick wall or capsule with a verticular pattern (BOSHKO, 1981; NYLUND, WESTMAN and LOUNATMAA, 1983). Many isolated observations of $P$. haeckeli have been reported in crayfish from different areas in Europe (HENTTONEN, HUNER and LINDQVIST, 1995; CERENIUS and SÖDERHÄLL, 1993; NOVOSELTCEV, PEPELYAEV and HENTTONEN, 1995; TAUGBØL and SKURDAL, 1992; BUCINSKIENE, 1996; VOGT, KELLER and BRANDIS, 1996; DIÉGUEZ-URIBEONDO et al., 1993). However, studies of the organism's distribution in the southeast of the continent are lacking. There were no data about its presence in astacid populations of Croatia. The objectives of this study were to investigate the possible presence of Psorospermium in some astacid populations in Croatia, and to determinate and describe the morphotype and life form, if possible. Twelve populations of the three native astacid species: noble crayfish Astacus astacus (Linne,1758), narrow-clawed crayfish Astacus leptodactylus (Eschscholtz, 1823) and stone crayfish Austropotamobius torrentium (Schrank, 1803) were screened for the presence/absence of Psorospermium.

\section{MATERIAL AND METHODS}

The presence/absence of Psorospermium in Croatian fresh waters was studied from 2001 to 2003. The majority of the collected crayfish came from the waters where other studies have been conducted at the same time and were fresh, living animals trapped during all seasons. Some examined specimens, mostly from streams and brooks, were collected during 1999 and were preserved in $70 \%$ ethanol. Twelve collection sites are presented on the map (Figure 1) and listed in Table I. Each collection site was inhabited by only one crayfish species. Three astacid species were examined for presence/absence of Psorospermium: Astacus astacus, Astacus leptodacylus and Austropotamobius torrentium. Two species of the Astacus genera were trapped overnight by baited LiNi traps. Total lengths of $A$. astacus were from 5.35 to $14.2 \mathrm{~cm}$ while total lengths of $A$. leptodactylus were from 4.5 to $10.9 \mathrm{~cm}$. Specimens of $A$. torrentium were collected by hand or trapped overnight by hand made small traps. Total lengths were from 5.5 to $11.1 \mathrm{~cm}$.

Three pieces of epidermal and connective tissue under the carapace, per individual, were examined for Psorospermium. They were prepared by scraping the tissue from under the carapace, treating it with $10 \% \mathrm{KOH}$ and pressing it slightly between a glass slide and a coverslip. Preparations were viewed under the microscope at $125 x, 250 x$ and $400 \times$ magnification. At $125 \times$ magnification, relative scale $(0=$ not present; $+=1-14$ organisms per field of view; $++=15-60$ organisms per field of view) was used to describe 


\section{Table I}

Occurrence of Psorospermium in different waterbodies in Croatia during 19992003. The number of the waterbody corresponds to the number on the map (Figure 1). Proportion of Psorospermium is presented as the number of infected crayfish/the number of crayfish investigated. Collection dates are presented as month/year.

\section{Tableau I}

Présence de Psorospermium dans différentes eaux de Croatie entre 1999-2003. Le numéro des stations correspond au numéro sur la carte (Figure 1). La proportion de Psorospermium est présentée comme le nombre d'écrevisses infectées/le nombre d'écrevisses analysées. Les dates sont indiquées en format mois/année.

\begin{tabular}{|c|c|c|c|c|c|}
\hline No. & $\begin{array}{l}\text { Name of the } \\
\text { waterbody }\end{array}$ & $\begin{array}{l}\text { Collection } \\
\text { month and/ } \\
\text { or year }\end{array}$ & Species & $\begin{array}{c}\text { Proportion } \\
\text { infected by } \\
\text { Psorospermium }\end{array}$ & $\begin{array}{c}\text { Relative } \\
\text { abundance }\end{array}$ \\
\hline 1. & $\begin{array}{l}\text { River Drava } \\
\text { - in Prelog }\end{array}$ & $12 / 2001$ & A. astacus & $2 / 2$ & ++ \\
\hline 2. & $\begin{array}{l}\text { Lake } \\
\text { Vukovina }\end{array}$ & $\begin{array}{l}04 / 2001 \\
10 / 2001 \\
10 / 2002 \\
07 / 2003 \\
08 / 2003\end{array}$ & A. astacus & $\begin{array}{l}0 / 11 \\
3 / 9 \\
0 / 35 \\
2 / 5 \\
0 / 6 \\
\end{array}$ & $\begin{array}{l}0 \\
+ \\
0 \\
+ \\
0\end{array}$ \\
\hline 3. & Lake Crno & $05 / 2001$ & A. astacus & $1 / 4$ & + \\
\hline 4. & $\begin{array}{l}\text { River Sava } \\
\text { - Lonjsko } \\
\text { Polje }\end{array}$ & $\begin{array}{l}05 / 2003 \\
06 / 2003 \\
07 / 2003\end{array}$ & A. leptodactylus & $\begin{array}{l}0 / 3 \\
3 / 5 \\
2 / 10\end{array}$ & $\begin{array}{l}0 \\
+ \\
+\end{array}$ \\
\hline 5. & Lake Bundek & $03 / 2003$ & A. astacus & $0 / 4$ & 0 \\
\hline 6. & $\begin{array}{l}\text { Stream } \\
\text { Mrzlak }\end{array}$ & 1999 & A. torrentium & $0 / 9^{*}$ & 0 \\
\hline 7. & Stream Sarni & 05/1999 & A. torrentium & $0 / 2^{*}$ & 0 \\
\hline 8. & Stream Veliki & $05 / 2001$ & A. torrentium & $0 / 10$ & 0 \\
\hline 9. & $\begin{array}{l}\text { Stream } \\
\text { Kraljevec }\end{array}$ & $\begin{array}{l}11 / 1999 \\
05 / 2003 \\
06 / 2003 \\
07 / 2003 \\
\end{array}$ & A. torrentium & $\begin{array}{l}0 / 1^{*} \\
0 / 6 \\
0 / 5 \\
0 / 6\end{array}$ & $\begin{array}{l}0 \\
0 \\
0 \\
0\end{array}$ \\
\hline 10. & $\begin{array}{l}\text { Stream in } \\
\text { Nature Park } \\
\text { Plitvice } \\
\end{array}$ & 1999 & A. torrentium & $0 / 6^{*}$ & 0 \\
\hline 11. & $\begin{array}{l}\text { River } \\
\text { Krapina }\end{array}$ & $07 / 2001$ & A. astacus & $0 / 4$ & 0 \\
\hline 12. & $\begin{array}{l}\text { River Sava } \\
\text { - Rajevo selo }\end{array}$ & $07 / 2003$ & A. leptodactylus & $0 / 1$ & 0 \\
\hline
\end{tabular}

\section{Abbreviations:}

* Specimens preserved in $70 \%$ ethanol.

Relative scale was used to describe abundance of the $P$. haeckeli in the subepidermal connective tissue at $125 x$ magnification ( 0 not present; $+=1-14$ organisms per field of view; $++=15-60$ organisms per field of view).

Abréviations :

* échantillon préservé dans $70 \%$ d'alcool.

L'échelle relative a été utilisée pour décrire l'abondance de $P$. haeckeli dans le tissu sub-épidermal à l'agrandissement $125 \times(0=$ non présent $;+=1$-14 organismes dans le champ de vue ; ++ = 15-60 d'organismes dans le champ de vue). 


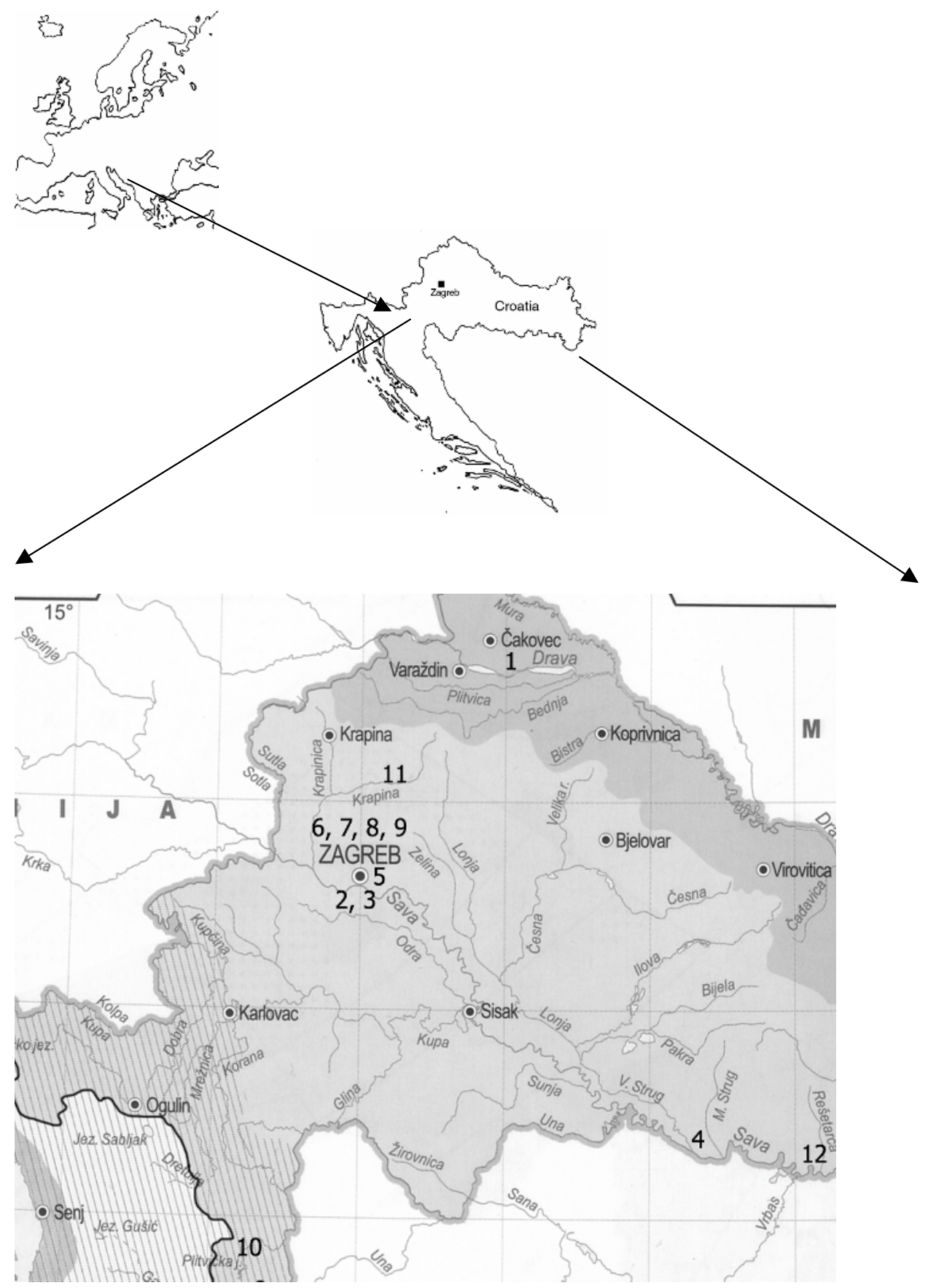

Figure 1

Location of the waterbodies where Astacus astacus, Astacus leptodactylus and Austropotamobius torrentium were collected from 1999 to 2003. In the waterbodies numbered 1-4 Psorospermium was present, in the waters number 5-12 Psorospermium was not found.

\section{Figure 1}

Localisation des stations où ont été prélevés les spécimens d'Astacus astacus, Astacus leptodactylus et Austropotamobius torrentium entre 1999-2003. Dans les stations 1 à 4 Psorospermium a été observé, dans les eaux 5 à 12 il n'y a eu aucune observation de Psorospermium. 
parasite abundance per individual. Relative parasite abundance within the population was based upon the average abundance of parasite within all infected animals. Specimens of epidermal-connective tissue of $A$. torrentium preserved in $70 \%$ ethanol were viewed under the microscope without $10 \% \mathrm{KOH}$ pretreament. The total number of crayfish examined was 144 , of which there were 80 specimens of $A$.astacus, 19 specimens of $A$. leptodactylus and 18 ethanol-preserved/27 fresh specimens of $A$. torrentium.

\section{RESULTS}

Psorospermium was observed in 4 out of 12 investigated wild populations. Three of them were noble crayfish $A$. astacus populations from northwest Croatia and one was narrow-clawed crayfish $A$. leptodactylus population from the Sava River in the middle part of Croatia (Figure 1).

Of two examined specimens of noble crayfish from the Drava River, both were infected with the mature form of Psorospermium sporocysts with fully developed structures (Figure 2). They were "shuttle-shaped", quite long and narrow (approx. $140 \mu \mathrm{m}$ long and $60 \mu \mathrm{m}$ wide) and slightly angular. Three visible layers surrounded the sporocysts: an innermost double-membraned layer, the cell wall, which was thick and amorphous, and a thick outer layer of shell plates. The sporocyst contained some large and a few very small globules scattered inside the cell. In both specimens there were between 15 and 20 organisms per field of view.

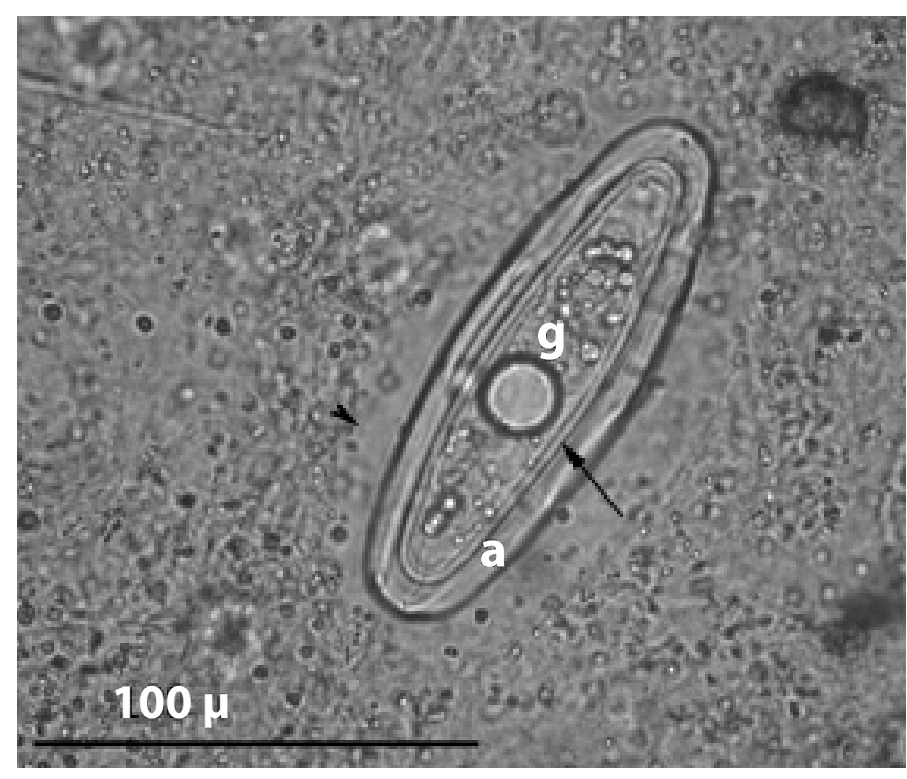

Figure 2

Elongated Psorospermium morphotype 2 found in the subepidermal connective tissue of Astacus astacus from the Drava River. Mature sporocyst with doublemembraned layer (arrow), thick and amorphous layer (a), and thick layer of shell plates (arrowhead). Globules (g) of different sizes are scattered inside the sporocyst. Bar scale $100 \mu \mathrm{m}$.

\section{Figure 2}

$P$. haeckeli de morphotype 2 de forme allongé trouvé dans le tissu conjonctif subépidermal d'Astacus astacus du fleuve Drava. Sporocyste mature avec la double couche membranaire (flèche), la couche épaise et amorphe (a) et la couche en feuillet épais (trait). Globules ( $g$ ) de tailles différentes situés dans la cellule. Echelle $100 \mu \mathrm{m}$. 
Of 66 noble crayfish from the Vukovina Lake, only 5 specimens were infected with Psorospermium, and of 4 examined crayfish from the Crno Lake, one specimen was infected. Sporocysts from those samples were different from that previously described. We found mature sporocysts (Figure 3A) of ovoid shape (approx. $100 \mu \mathrm{m}$ long and $50 \mu \mathrm{m}$ wide) with the three characteristic layers. However, the outermost shell plate layer was much thinner than previously described. Globules of different sizes were mixed together inside the cell and they were not so prominent. Also, in crayfish trapped during July 2003 we noticed differentiating stages of Psorospermium sporocysts (Figure 3B), which were ovoid with two layers partly developed: thick medium amorphous layer and outermost thin layer of shell plates. Never were more then 5 organisms observed per field of view.

Of 19 examined narrow-clawed crayfish from the Sava River, 6 were infected with Psorospermium. Mature sporocysts (Figure 4A) were elongated and quite narrow (approx. $180 \mu \mathrm{m}$ long and $70 \mu \mathrm{m}$ wide), surrounded with the fully developed and visible three characteristic layers. The outermost layer was very thick and consisted of many shell plates. The cell was completely filled with numerous and uniform small globules or, in some cases, contained a few big and many small globules. When there were more than 10 sporocysts per field of view, many of them were melanised (Figure 4B). In one sample, taken in July 2003, we found differentiating stages of Psorospermium (Figure 4C), which were very similar to those, previously described for noble crayfish from the Vukovina Lake, but there were no mature sporocysts in that sample. In 5 cases there were between 5 and 10 organisms per field of view. Only one crayfish was more heavily infected and it had approximately 15 organisms per field of view.

Psorospermium sporocysts were not detected in crayfish from the other 8 locations. Moreover, no stone crayfish was found to be infected.
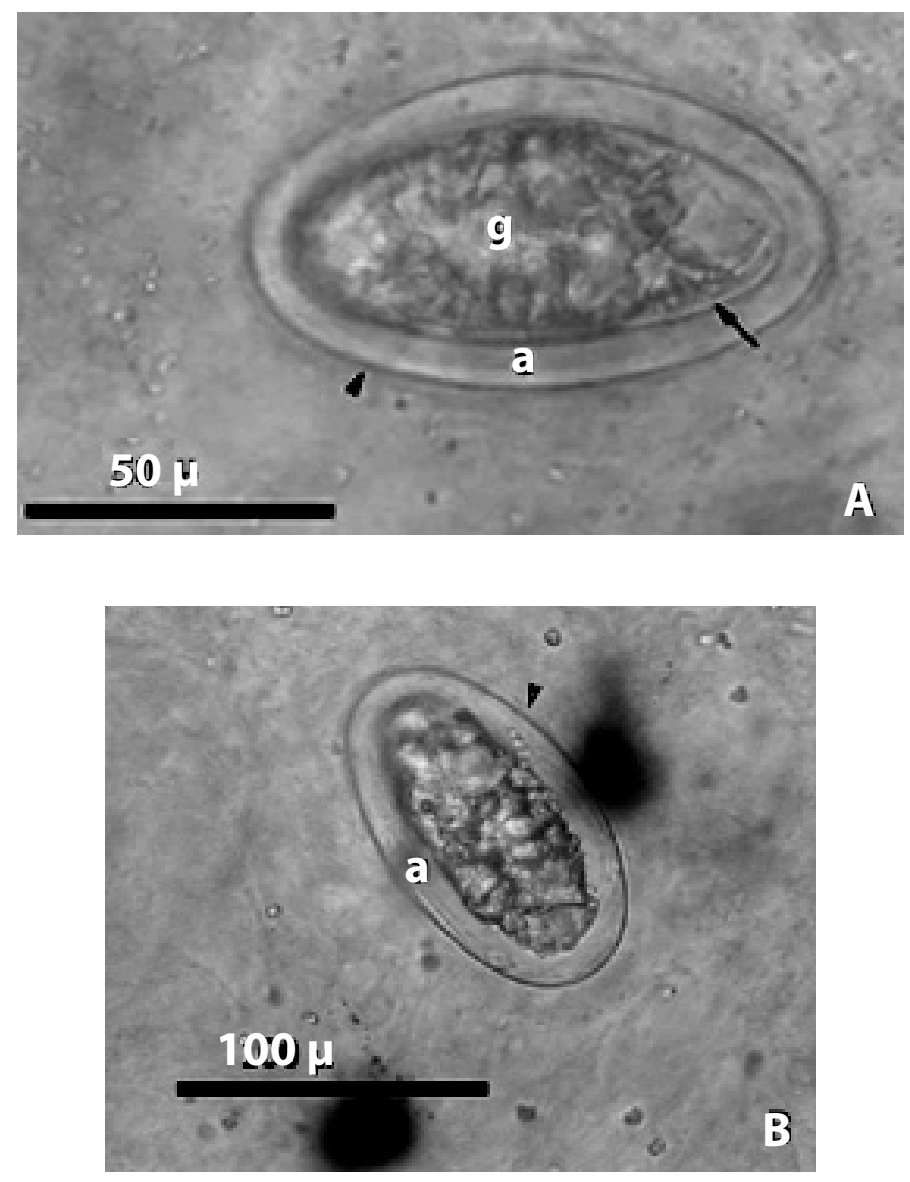


\section{DISCUSSION}

Our investigation represents the first survey for Psorospermium in Croatia. It shows that this parasite is present in two out of four native Croatian astacid crayfish (MAGUIRE, 2002). P. haeckeli was described in Central Europe in 1857 by HAECKEL (1857) and according to WIERZEJSKI (1888) it was found in many localities in Galizia (Poland) at the end of the $19^{\text {th }}$ century. There were almost no data published about its presence in crayfish of southeast Europe or in countries neighbouring Croatia. HENTTONEN, HUNER and LINDQVIST (1997) examined one specimen of $A$. leptodactylus and one $A$. astacus from Hungary and failed to detect $P$. haeckeli. However, as we found Psorospermium in noble crayfish from the Drava River, which is bordering Hungary, we could assume that infection exists there but data are lacking. It is interesting that in those two specimens of noble crayfish we found the elongate Psorospermium morphotype that is frequently found in narrow-clawed crayfish (VEY, 1979) and only occasionally in noble crayfish (GRABDA, 1934). RUG and VOGT (1995) described two different morphotypes of $P$. haeckeli which may represent species: the ovoid Psorospermium sp. 1 which seems to be common in Astacus astacus and elongate Psorospermium sp. 2 which was usually found in Astacus leptodactylus. They, as well as other authors (NYLUND and WESTMAN, 1995), found that elongate Psorospermium sp. 2 morphotype could be mixed together with the ovoid Psorospermium sp. 1 morphotype in tissues of noble crayfish. However, in the two observed noble crayfish from the Drava River we found only elongate Psorospermium sp. 2 morphotype. These sporocysts were slightly different from the typical elongated one described by RUG and VOGT (1995). Their globules were of different sizes, scattered around the cell and not as numerous (Figure 2). Due to the relatively high abundance of Psorospermium in noble crayfish from the Drava River (Table I), and the fact that both specimens were infected we could assume that this population has high infection rate. However, more detailed investigations are needed for confirmation.

The typical elongated Psorospermium sp. 2 morphotype was found in narrowclawed crayfish from the Sava River in the middle part of Croatia. There are many reports of infection of $A$. leptodactylus by $P$. haeckeli (FÜRST and SÖDERHAÄLL, 1987; NOVOSELTCEV, PEPELYAEV and HENTTONEN, 1995; BUCINSKIENE, 1996). We found that 5 out of 19 observed crayfish were infected with elongated Psorospermium sp. 2 morphotype, typical for narrow-clawed crayfish (Figure 4A). This type of Psorospermium

\section{Figure 3}

Mature and developing ovoid sporocysts of Psorospermium morphotype 1 found in the subepidermal connective tissue of Astacus astacus from the Vukovina Lake and Crno Lake. (A) Mature ovoid sporocyst of Psorospermium sp. 1 morphotype with double membraned layer (arrow), amorphous layer (a), and outermost thin shell plate layer (arrowhead). Less prominent globules (g) inside the sporocyst. Bar scale $50 \mu \mathrm{m}$. (B) Differentiating ovoid sporocyst with two layers: medium amorphous layer (a) and a thin layer of shell plates (arrowhead). Bar scale $100 \mu \mathrm{m}$.

\section{Figure 3}

Sporocystes ovoïdes matures et en développement de Psorospermium de morphotype 1, trouvés dans le tissu conjonctif sub-épidermal d'Astacus astacus dans les lacs Vukovina et Crno. (A) Sporocyste ovoïde mature du Psorospermium $s p$. Morphotype 1 avec une couche membranaire double (flèche), une couche amorphe (a) et une mince couche en feuillet (pointe de flèche). Globules (g) nonaccentués dans la cellule. Echelle $50 \mu \mathrm{m}$. (B). Sporocyste ovoïde au stade avec deux couches : une couche médiane amorphe (a) et une couche en feuillet (pointe de flèche). Echelle $100 \mu \mathrm{m}$. 

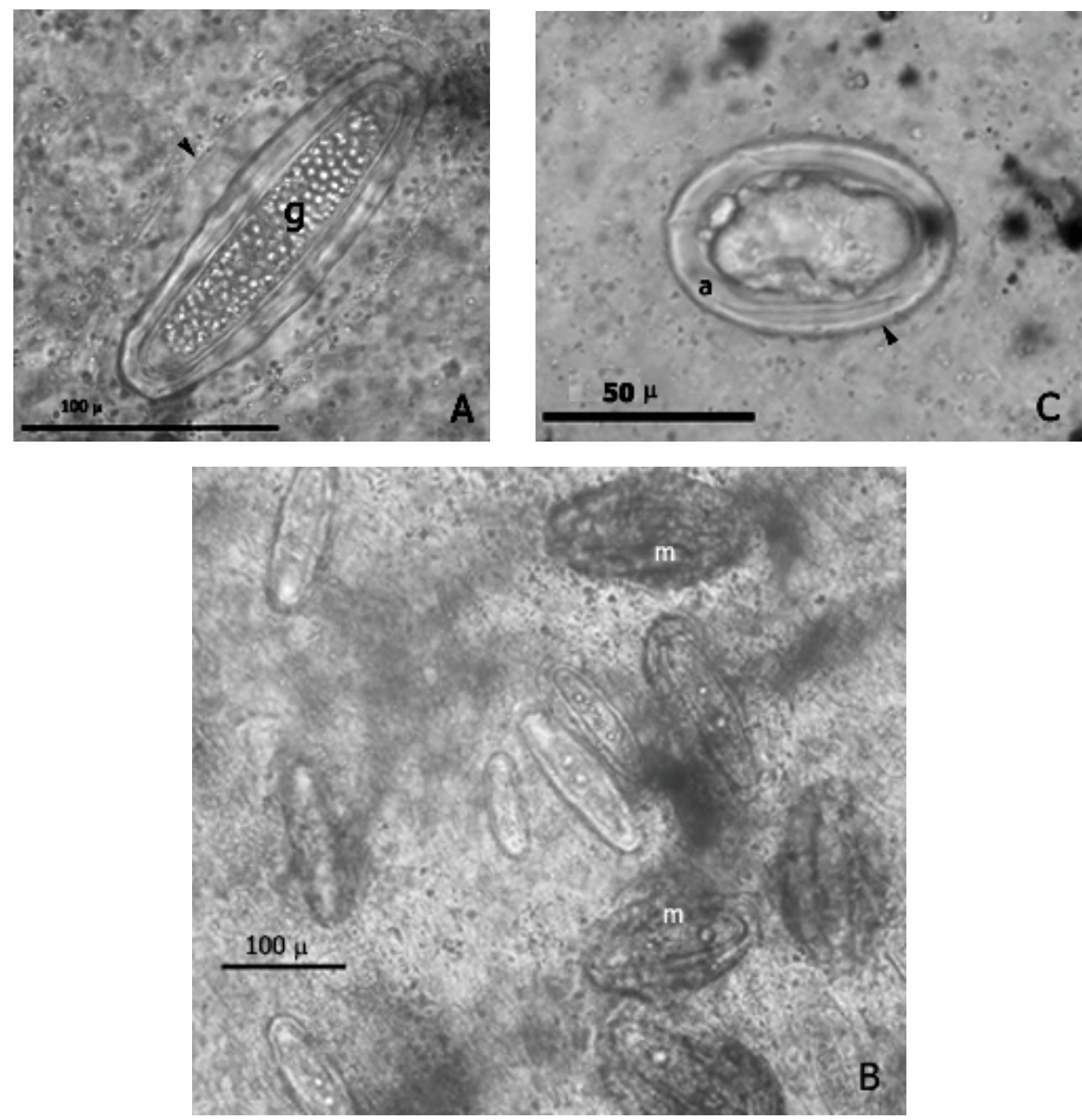

Figure 4

Mature and developing sporocyst of Psorospermium found in the subepidermal connective tissue of Astacus leptodactylus from the Sava River. (A) Elongated mature sporocyst of Psorospermium sp. 2 morphotype with a very thick layer of shell plates (arrowhead) and filled with many uniform small globules (g) Bar scale $100 \mu \mathrm{m}$. (B) Melanised Psorospermium sp. 2 morphotype sporocysts (m) Bar scale $100 \mu \mathrm{m}$. (C) Differentiating sporocyst of Psorospermium sp. 1 morphotype with an amorphous layer (a) and a shell plate layer (arrowhead). Bar scale $50 \mu \mathrm{m}$.

Figure 4

Sporocyste de Psorospermium mature et en phase de développement trouvé dans le tissu conjonctif sub-épidermal d'Astacus leptodactylus dans le fleuve Sava. (A) sporocyste mature allongé de Psorospermium sp. Morphotype 2, avec une très épaisse couche en feuillet (flèche), et rempli de petits globules (g). Echelle $100 \mu \mathrm{m}$. (B). Sporocystes mélanisés (m) de Psorospermium sp. 2 Echelle $100 \mu \mathrm{m}$. (C). Sporocystes de Psorospermium sp. de morphotype 1 en développement avec une couche amorphe (a) et une couche en feuillet (pointe de la flèche). Echelle $50 \mu \mathrm{m}$. 
had a prominent envelope of connective tissue produced by the host consistent with the description given by RUG and VOGT (1995). In one heavily infected crayfish Psorospermium induced immune reactions including weak melanisation (Figure 4B). This is contrary to the findings of RUG and VOGT (1995) where only Psorospermium sp. 1 induced melanisation. Differentiating stages found in one crayfish sample were more similar to those of Psorospermium sp. 1 ovoid type described by VOGT and RUG (1999). However, as no mature sporocyst were observed in the sample it was not possible to determine if the crayfish was infected with the Psorospermium sp. 1 morphotype typical for noble crayfish.

Obviously, different morphotypes of Psorospermium are not exclusively present in particular astacid species which is consistent with findings of other authors (GRABDA, 1934; NYLUND and WESTMAN, 1995).

Noble crayfish from the two small and closely located gravel pits in the north-west of Croatia were also infected by the Psorospermium. Proportion of Psorospermium in the Vukovina Lake, where 66 crayfish were sampled, was not very high. Only 5 specimens were infected. Due to the very low abundance of the parasite in the subepidermal connective tissue of these crayfish (1-5 organisms per field of view) it is possible that others in the sample were infected at the level which did not allow detection by this method. In crayfish from both gravel pits, ovoid Psorospermium sp. 1 morphotype, described by RUG and VOGT (1995), was found. Typical sporocysts of ovoid shape, with a thin outermost shell plates layer and globules of different sizes, were found in many A. astacus populations in Scandinavian countries (HENTTONEN, HUNER and LINDQVIST, 1994; TAUGBØL and SKURDAL, 1995; CERENIUS and SÖDERHAÄLL, 1993). Our findings confirm that the ovoid Psorospermium is a typical morphotype for A. astacus. Differentiating stages of Psorospermium found in tissue samples of crayfish from the Vukovina Lake (Figure 3B) were also of Psorospermium sp. 1 type and similar to those described by VOGT and RUG (1999).

Although $P$. haeckeli was detected in the stone crayfish $A$. torrentium by other authors (VEY, 1979), especially when it coexisted with the noble crayfish $A$. astacus (VOGT, KELLER and BRANDIS, 1996) we have never found infected specimens in this species. One reason could be that many tissue specimens were not fresh but were preserved in ethanol. However, such specimens were used by Spanish authors (DIÉGUEZ-URIBEONDO et al., 1993) and resulted in positive findings of Psorospermium. On the other hand, as we found no evidence of infection in fresh specimens, we could assume that the stone crayfish populations studied were not infected with the Psorospermium.

\section{CONCLUSION}

This investigation confirmed that Psorospermium does infect astacid populations in Croatia. Psorospermium was detected in A. astacus and A. leptodactylus, and not in A. torrentium. Two characteristic and earlier described morphotypes of Psorospermium sporocysts were found: ovoid and elongated morphotypes. Both morphotypes were present in noble crayfish and narrow-clawed crayfish but were never present in the same crayfish sample.

It is difficult to make any kind of conclusions on the causes of the distribution of Psorospermium in Croatia observed in this study. Firstly, the data collected were the first of their kind and more data are required. Secondly, it is still unknown how the parasite is spreading between crayfish and research is required to determine how distribution is correlated with other population parameters and with hydrodynamics. Finally, there is no data on the occurrence of Psorospermium in neighbouring countries. 


\section{REFERENCES}

BOSHKO E., 1981. The parasites and symbionts of the river crab, Astacus (Potamobius) leptodactylus Esch. in the river Udai (Dnepr Basin). Vestnik Zoologii, 6, 73-76.

BUCINSKIENE R., 1996. Occurrence and relative abundance of Psorospermium haeckeli in Lithuanian crayfish. Freshwater Crayfish, 11, 494-499.

CERENIUS L., SÖDERHAÄLL K., 1993. The distribution of Psorospermium haeckeli in Sweden; a preliminary survey. Freshwater Crayfish, 9, 280-285.

DIÉGUEZ-URIBEONDO J., PINEDO-RUíZ J., CERENIUS L., SÖDERHAÄLL K., 1993. Presence of Psorospermium haeckeli (Hilgendorf) in a Pacifastacus leniusculus (Dana) population of Spain. Freshwater Crayfish, 9, 286-288.

EVANS L.H., EDGERTON B.F., 2002. Pathogens, Parasites and Commensals. In HOLDICH D.M. (ed.) Biology of Freshwater Crayfish, Blackwell Science, Oxford, 408-411.

EVANS L.H., JUSSILA J., 1996. Morphology and prevalence of Psorospermium sp. in farmed and wildstock freshwater crayfish populations in Western Australia. Freshwater Crayfish, 11, 481-493.

FÜRST M., SÖDERHAÄLL K., 1987. The crayfish Astacus leptodactylus in Turkey. Diseases and present distribution of the crayfish plague fungus, Aphanomyces astaci. FAO Report, Rome, Italy, 26.

GRABDA E., 1934. Recherches sur un parasite de l'écrevisse (Potamobius fluviatilis L.) connu sous le nom de Psorospermium haeckeli Hlgd. Mémoires de l'Académie Polonaise des Sciences et des Lettres, Cracovie, Série B, 6, 123-142.

HAECKEL E., 1857. Über die Gewebe des Flusskrebses. Archieves für Anatomie, Physiologie Und Wissenshaftliche Medicin, 24, 561-562.

HENTTONEN P., LINDQVIST O.V, HUNER J.V., 1992. Incidence of Psorospermium sp. in several cultivated populations of crayfishes, Procambarus spp. (Decapoda, Cambaridae), in Southern Louisiana. Journal of World Aquacultura Society, 23/1, 31-37.

HENTTONEN P., 1996. The parasite Psorospermium in freshwater crayfish. Kuopio University Publications, Natural Environmental Science, 48, 1-78.

HENTTONEN P., HUNER J.V., LINDQVIST O.V., 1994. Occurrence of Psorospermium sp. In several North American crayfish species, with comparative notes on Psorospermium haeckeli in European crayfish, Astacus astacus. Aquaculture, 120, 209-218.

HENTTONEN P., HUNER J.V., LINDQVIST O.V., 1995. Observation on Psorospermium haeckeli in noble crayfish Astacus astacus (L.) (Decapoda, Astacidae) populations in Central Finland. Freshwater Crayfish, 10, 339-351.

HENTTONEN P., HUNER J.V., LINDQVIST O.V. (1997). A comparison of the known life forms of Psorospermium spp. in freshwater crayfishes (Arthropoda, decapoda) with emphasis on Astacus astacus L. (Astacidae) and Procambarus clarkii (Girard) (Cambaridae). Aquaculture, 149 (1-2), 15-30.

MAGUIRE I., 2002. Family Astacidae in north-west Croatia. Doctoral Thesis (in Croatian with English abstract), Faculty of Science, University of Zagreb, 12-13.

MENDOZA L., TAYLOR J.V., AJELLO L., 2002. The Class Mesomycetozoea : A Heterogenous Group of Microorganisms at the Animal Fungal Boundary. Annu. Rev. Microbiol., $56,315-344$.

NOVOSELTCEV G.E., PEPELYAEV I.B., HENTTONEN P., 1995. Occurrence of the pathogen Psorospermium haeckeli in Karalla. Biological resources of the White Sea 
and Inland waters of the european north, Petrozavodsk, Russia, 19-23 November 1995, book of abstracts.

NYLUND V., WESTMAN K., LOUNATMAA K., 1983. Ultrastructure and taxonomic position of the crayfish parasite Psorospermium haeckeli Hilgendorf. Freshwater Crayfish, 5, 307-314.

NYLUND V., WESTMAN K., 1995. On the chemical structure and taxonomic position of the crayfish parasite Psorospermium haeckeli Hilgendorf. Freshwater Crayfish, 10, 352-362.

RUG M., VOGT G., 1995. Histology and histochemistry of developing and mature spores of two morphotypes of Psorospermium haeckeli. Freshwater Crayfish, 10, 374384.

TAUGBØL T., SKURDAL J., 1992. Parasitten Psorospermium haeckeli påvist i norske krebsebestander. Fauna, 45, 32-39.

TAUGBØL T., SKURDAL J., 1995. Occurrence and relative abundance of Psorospermium haeckeli in Norwegian noble crayfish Astacus astacus populations. Freshwater Crayfish, 10, 388-395.

THÖRNQVIST P.O., SÖDERHAÄLL K., 1993. Psorospermium haeckeli and its interaction with the crayfish defence system. Aquaculture, 117, 205-213.

VEY A., 1979. Recherches sur une maladie des écrevisses due au parasite Psorospermium haeckeli Hilgendorf. Freshwater crayfish, 4, 411-418.

VOGT G., 1999. In vitro induction of further development of sporocysts of the crayfish parasite Psorospermium haeckeli. Freshwater Crayfish, 12, 319-334.

VOGT G., KELLER M., BRANDIS D. 1996. Occurrence of Psorospermium haeckeli in the stone crayfish Austropotamobius torrentium from a population naturally mixed with the noble crayfish Astacus astacus. Diseases of Aquatic Organisms, DAO, 25, 233238.

VOGT G., RUG M., 1995. Microscopic anatomy and histochemistry of the crayfish parasite Psorospermium haeckeli. Diseases of Aquatic Organisms, 21(2), 79-90.

VOGT G., RUG M., 1999. Life stages and tentative life cycle of Psorospermium haeckeli, a species of the novel DRIP's clade from the animal-fungal dichotomy. Journal of Experimental Zoology, 283, 31-42.

WIERZEJSKI A., 1888. Kleiner Beitrag zur Kenntnis des Psorospermium haeckelii. Zoologischer Anzeiger, 11, 230-231. 
